Капцова, Юлія. «Фенаменалогія жывога слова: даніна памяці і вартасць незабыўнага». Лінгвостилістичні студії, вип. 12, 2020, с. 73-82.

Kaptsova, Yuliya. "Phenomenology of a Living Word: a Tribute to the Memory and Dignity of the Unforgettable". Linguostylistic Studies, iss. 12, 2020, pp. 73-82.

УДК 811.161.3'373:165.62

https://doi.org/10.29038/2413-0923-2020-12-73-82

\title{
ФЕНАМЕНАЛОГІЯ ЖЫВОГА СЛОВА: ДАНІНА ПАМЯЦІ І ВАРТАСЦЬ НЕЗАБЫЎНАГА
}

\author{
Юлія Капцова \\ Брэсцкі дзяржаўны ўніверсітэт імя А. С. Пушкіна, \\ Брэст, Беларусь
}

у артыкуле даследуюцца фенаменалагічныя аспекты антыноміі “памятнае і незабыўнае”. Феномен незабыўнага звязваецца 3 археалагічным падыходам да ўвасобленай у слове відавочнай рэальнасці, даследаваннем глыбінных сэнсавых структур мовы, яе "ўнутраных" форм. У святле фенаменалагічнага падыходу паўстае пытанне аб выяўленні ў мове сутнасцей (феноменаў) і сэнсавай шматвектарнасці слова ў непасрэднай гаворцы. Надаецца ўвага моўцу, ствараюцца перадумовы даследавання жыццёвага свету - фенаменалагічнай рэальнасці, увасобленай у кантынуальнай стыхіі жывога слова.

Ключавыя словы: незабыўнае, памяць, фенаменалогія, археалогія мыслення, жывое слова.

Капцова Юлія. Феноменологія живого слова: данина пам'яті та цінність незабутнього. У статті досліджуються феноменологічні аспекти антиномії «пам'ятне і незабутнє». Феномен незабутнього зв'язується з археологічним підходом до втіленої в слові очевидної реальності, дослідженням глибинних смислових структур мови, їі «внутрішніх» форм. У світлі феноменологічного підходу постає питання про виявлення в мові сутностей (феноменів) і смисловий багатовекторності слова в безпосередній мови. Приділяється увага мови, створюються передумови дослідження життєвого світу - феноменологічної реальності, втіленої в континуальної стихії живого слова.

Ключові слова: незабутнє, пам'ять, феноменологія, археологія мислення, живе слово.

\section{PHENOMENOLOGY OF A LIVING WORD: A TRIBUTE TO THE MEMORY AND DIGNITY OF THE UNFORGETTABLE Yuliya Kaptsova}

Brest State A. S. Pushkin University, Brest, Republic of Belarus

The article elucidates the issues of the general anthropocentric orientation of modern linguistic research, taking into account the "human" factor and through the prism of subjective vision of the world. Scholars believe that a word is not only a way of exchanging thoughts but also a form of interaction of people, a means of stimulating their consciousness, will and emotions, a way to achieve mutual understanding in society, or a failure to achieve it.

(C) Капцова Ю., Східноєвропейський національний університет імені Лесі Українки, 2020.

Це стаття відкритого доступу на умовах CC BY-NC 4.0 
The article examines the phenomenological aspects of the Belarusian word, using the antinomy memorable and unforgettable as a case study. The phenomenon of the unforgettable is associated with the archaeological approach to the obvious reality embodied in the word, the study of the deep semantic structures of the language, its "internal" forms. Using the phenomenological approach, the study seeks to reveal the phenomena of multi-vector word usage in live speech and interpret their semantics. In the focus is the language as the prerequisite for the study of the life world - a phenomenological reality embodied in the continuum of the living word.

The characteristic features of a living word are justified, and a living word is considered not as a part of a sign system (which is accepted in the traditional approach) but as the reality of metalinguistic creativity. The distinguishing features of a living word are identified: eidetic nature, impressive (graphic) nature, text formation ability, lack of pragmatic significance, non-discursiveness, semantic elusiveness ("diverse semantic vectoriality").

The significance of the results of the work is obvious since they stimulate the continuation of the phenomenological study of Belarusian language reality. The linguistic phenomenology in this context can be considered as a promising direction that can explain the principle of linguistic variability of a living word, as well as the contradiction between symbols and their infinity of meanings expressed by them.

Key words: unforgettable, memory, phenomenology, archeology of thinking, a living word.

Уводзіны. Сучасная лінгвістыка прыкметна перастае быць навукай артадаксальнай і ўсё больш звяртаецца да чалавека, які гаворыць (моўцы), стараецца дакапацца да глыбінь ажыццяўлення яго аўтэнтычнасці, перадумоў творчага станаўлення, закрануць парадоксы жыцця. Прадметам разгляду становіцца «жывая мова жывога чалавека» (М. Бахцін) выяўленне ў слове разнастайных сэнсавых вектараў і характару моўных паводзін. Лінгвістыка набывае аблічча эйдычнай навукі і пачынае служыць жыццю - узнаўляе страчаную сувязь 3 найглыбейшымі чалавечымі клопатамі. Як антытэза традыцыйнаму паняццю культуры маўлення і адлюстраванню кодаў культуры ў лінгвістычнае даследаванне ўводзіцца аспект цывілізаванасці слова, увасабленне ў ім шыфраў творчага недыскурсіўнага метапазнання. Аспект вербальнай рэфлексіі («Як наша слова адгукнецца?») заслугоўвае, на нашу думку, не меншай увагі, чым даследаванне мовы як функцыянальнай семіятычнай сістэмы.

Айчыннае мовазнаўства не знаходзіцца ў баку ад прыярытэтных напрамкаў сусветнай лінгвістыкі. I хаця сам тэрмін фенаменалогія ў кантэксце даследавання мовы беларускай лінгвістыкай пакуль што не атрымаў распаўсюджання, у сапраўднасці айчынныя мовазнаўцы даследавалі і даследуюць слова з фенаменалагічнага пункту гледжання, называючы аб'ект свайго даследавання «жывым словам».

Мэта артыкула - даследаванне беларускага слова ў фенаменалагічным аспекце.

Матэрыял і метады даследавання. Матэрыялам для артыкула паслужылі факты, узятыя 3 тэкстаў мастацкіх твораў беларускай літаратуры і перыядычнага друку. Прыводзяцца прыклады з вуснага маўлення і прастамоўя. Выкарыстоўваецца лексікаграфічная інфармацыя 3 
Тлумачальнага слоўніка беларускай мовы і Popularniego słownika języka polskiego.

Метадалагічнай базай даследавання з'яўляецца філасофія рэальнасці Э. Гусерля. Менавіта у фенаменалагічным напрамку культывуецца ідэя рефлексіўнасці слова, выяўленне ў слове разнастайных сэнсавых вектараў і характару моўных паводзін чалавека.

Аснову методыкі даследавання складае аспект супрацьпастаўлення імпрэсіі (увасаблення) вербальнага этасу і ўласцівай пафасу экспрэсіі (выражэння), што праяўляецца ў адрозненні адзінак экстэнсіянальных (іменных) кантэкстаў i элементаў кантэкстаў інтэнсіянальных кантэкстаў меркавання.

Вынікі даследавання і дыскусія. Характэрнай рысай жывога слова выступае яго немемарыяльнасць (ад лац. memorialis - памятны). У ім увасабляецца не памятнае, а незабыўнае: незабыўны 'такі, што нельга забыць' (Тлумачальны 3: 366). Памяць ахвярная і пафасная. Незабыўнае выяўляе характар велічнага і непасрэдна перажываецца чалавекам: Велічныя і незабыўныя хвіліны перажывалі людзі (М. Паслядовіч). Мой родны кут, як ты мне мілы!.. Забыць цябе не маю сілы! (Я. Колас). Рэальнасць, да якой прыкладваецца эпітэт незабыўнае, рэхам адгукаецца ў самой істоце чалавека, належыць глыбінным пластам яго ментальнасці: незабыўнае падарожжа, незабыўнае лета, незабыўнае дзяцінства і інш.

Не забываецца незвычайнае. Звычай як інстытут традыцыйнай культуры належыць «прозе жыцця» - штодзённасці, дзе ўсё адбываецца як звычайна. Да незвычайнага яшчэ не прывыклі - яго не было ў папярэднім вопыце: Сын першы раз завітаў у лес, і уссё тут яму было незвычайнае, невядомае (У. Кандрусевіч). Незвычайнае выяўляецца ў непасрэдным пазнавальным вопыце суб'екта, які Б. Расел назваў «знаёмствам» (Павилёнис 286). Не бывае незвычайнага наогул, ёсць незвычайнае для каго. У незвычайным не адлюстроўваецца аб'ектыўная рэчаіснасць, аднак выяўляецца фенаменалогія суб'ектыўнага светаўспрымання. Другая назва незвычайнага - фенаменаменальнае. Феномен не з'ява аб'ектыўнай рэчаіснасці, якая нам адкрываецца, а тое, што само праходзіць і выяўляе сябе ў прысутнасці ўспрымальніка - другога (Философский 688).

Рэха незабыўнага - згадка. Змест дзеяслова згадаць звязаны 3 ірацыянальнай сферай чалавека - інтуітыўным угадваннем: Згaдай $\boldsymbol{n a}$ тваёй хадзьбе, у які ты імкнешся горад (П. Глебка). Нярэдка згадка атаясамліваецца з успамінам: згадка 'ўспамін' (Тлумачальны 2: 449). Аднак відавочна, што ўспамін не тое, што згадка. Пры ўспаміне ўзнаўляецца (уваскрасае) у памяці гістарычнае былое: Сваёю рукою на ім напісала яна /Алеся/: «На ўспамін аб былым» (А. Куляшоў). Згадваецца архаічнае мінулае - антыномія былога: параўн. пол. było-mineło; Co było, to było. Mineło jak miłość... (3 песні). Фенаменалогія ўспрымання адыходзіць ад прынцыпу гістарызма і арыентуецца на археалогію мыслення. 
У выразе было і прайшло за дзеясловам прайсці не стаіць гістарычная памяць. Гістарычнае адбываецца, а архаічнае праходзіць - маніфестуецца. Памяць уваскрашае былое, якое актуальна ўжо не існуе, а ў згадцы ажывае даўняе. Мінулага не было. Нельга сказаць, напрыклад, што мінулае лета гэта ўжо гісторыя. Яно можа ўвайсці ў гісторыю пэўнымі падзеямі і фактамі, але само гісторыяй не з'яўляецца. Згадка аб ім як бы рэанімуе (ажыўляе) тое, што даўно канула ў Лету - міфічную раку забыцця.

Архаічнае мінулае выяўляецца ў прасторавай метафары (далёкая мінуўшчына), характарызуецца глыбінёй (глыбокае мінулае). Для чалавека яно аказваецца даўно знаёмым. Суб’ектыўна знаёмае супрацьпастаўляецца вядомаму - набытым ведам, дзякуючы якім фарміруюць сацыяльны твар асобы, параўн.: мой даўні знаёмы, але: <Імярэк> вядомы як..., вядомы (дзе?), слаўны (чым?). Прэзентатыўнае словазлучэнне «мой знаёмы» не з'яўляецца ацэначным («знаёмы, і толькі»; «знаёмы, і больш нічога»). Пад ім хаваецца несказанае - важны сэнс для таго, хто гаворыць, перажыты жыццёвы вопыт. Суб'ектыўны вопыт не мае цаны, але аказваецца вартасным для чалавека. Вартасць чалавека таксама ўспрымаецца ў кантэксце яго знаёмства («Знаёмы самога N.»). У сувязі з фенаменальным вопытам узнікае парадокс. Усё што мае цану, нічога не варта, а тое, што чагосьці вартае, - бясцэннае. Апошняе стасуецца 3 жыццём - цэласнай фенаменальнай рэальнасцю.

Былое ўспамінаецца, а далёкае даўняе прыгадваецца: Прыгадваецца іншы раз чалавеку далёкае, перажытае... (А. Пальчэўскі). Узгадванне прысутнічае ў творчасці - недыскурсіўным пазнанні свету. Мастак валодае дарам пранікнення у сутнасць рэчаў, якая не выражаецца ў агульных паняццях. Дзеяслоў згадаць характэрны, напрыклад, для творчасці праф. Ф. Янкоўскага. У абразку «А мая ты, журавіначка!» аўтар як бы наўмысна пазбягае ўжываць словы, што маюць дачыненне да памяці: успамінаць, успамінаецца, успамін і да т.п. Героям абразка падчас рэфлексіі над словам нешта само сабой прыгадваецца: Потым удвух прыгадваем Гогаля: «Иное слово дороже вещи»; Як адказ на пытанне, я прыгадваю госцю сёе-тое 3 жывых, сённяшніх гаворак (Дарашэвічы, Галубіцы, Славінск, Лескавічы)... На нашай сустрэчы і на нашых сустрэчах прыгадвалася багата чаго (Ф. Янкоўскі).

Памяць дыскурсіўная. Сам дыскурс разумеецца як гістарычнае апавяданне. «Апавяданне робіць з усякай рэчы здань самой сябе, аддаляе яе, перакідвае за гарызонт актуальнасці. Расказанае ўжо «было» і гэтае «было» - форма, якую пакідае ў сучаснасці тая сутнасць, што цяпер ужо адсутнічае, як скура, скінутая змяёй» (Ортега-и-Гассет 103). Асновай бытавога і інстытуцыянальнага дыскурсаў з'яўляецца гістарычны фон. Былое - звычайны прадмет дыскурсу: Можа, ты пра былое жыццё сваё, браце, раскажаш? (М. Танк); быль 'расказ, апавяданне' (Тлумачальны 1: 429). Слова бывала ўжываецца як часціца і паказвае на дзеянне, якое паўтаралася раней: Іду, бывала,... Прыхожу, бывала і г. д. Бытавым 
дыскурсам з'яўляюцца ўспаміны тыпу: - А помніш, як... - А ўспомніце, калі мы... Як не ўспомніць... Помню, як зараз і інш. Успаміны могуць суправаджаюцца патэтыкай, напр.: Успомнім сваіх герояў! Пружанцы далучающца да акцыі «Беларусь памятае. Родныя твары Перамогі» («Успомнім»).

Выраз «Я иябе запомніў» з'яўляецца дэкларатыўным маўленчым актам і належыць бытавому дыскурсу. Як і іншыя дэкларацы, ён уносіць змены ў існуючае становішча спраў. Аднак прыведзены выраз зусім не тоесны неакцыянальнаму прызнанню: «Век цябе не забуду». Маўленчым актам можа заканчвацца камунікацыя («Сказаў і ўсё»), а прызнанне выступае пачаткам разгортвання тэксту. Той, хто прызнаецца, становіцца на шлях паглыбленай канкрэтызацыі рэальнасці: Не забуду тваіх иудоўных вачэй, непаўторнага тэмбру тваёй гаворкі, чароўных гукаў тваёй мовы і г. д. У ходзе канкрэтызацыі рэферэнт як бы сам па сабе вырысоўваецца. Аўтар не стварае дакладны вобраз (карціну), але рысуе эйдас (малюнак) рэаліі, стараючыся не абмінуць ні адной яе рысы. У эйдасе акцэнтуецца аспект цэласнасці.

Шлях канкрэтызацыі - шлях творчасці. Характэрна, што стан творчага захаплення аказваецца як бы станам забыцця: Манг зноў захапіўся працай і забыўся на голад (Я. Маўр); забыццё 'стан глыбокай задуменнасці, адлучанасці ад ўсяго навакольнага' (Тлумачальны 2: 282); параўн. рус. творческая отрешенность. Тэмай мастацкай творчасці становіцца тое, што не варта забываць: Я не забуду ніколі Сшыткі, пеналы, буквар, Першыя радасці ў школе, Першай настаўніцы твар. Я не забуду ніколі Рукі яе, што вялі Нас, як па роднаму полю, Па неабсяжнай зямлі. Я не забуду ніколі Ясных і добрых вачэй. Можа, ад іх наваколле Стала шырэй $і$ ярчэй. Першай настаўніцы словы, Дзе мне не здарыцца быць, Так, як $і$ матчыну мову, Нельга ніколі забыць (С. Грахоўскі).

У згаданым вершы С. Грахоўскага рэферэнтную вобласць складаюць «неадчужальныя прыналежнасці» чалавека (твар, рукі першай настаўніцы), а таксама ўсё тое, без чаго сапраўдны вучань як бы і не вучань (сшыткі, пяро і буквар). Незабыўнымі аказваюцца словы, без якіх чалавек як бы і не чалавек. «Мастацтва - як бы жыццё» (Ортега-и-Гассет 227). Характэрны для мастацтва сэнс «як бы» не ўказвае на параўнальнасць. Фенаменальны свет не пазнаецца праз прапорцыю. Тое, што «як бы», не напамінае рэалію, а аказваецца яе мастацкай рэцэпцыяй - нагадвае саму натуру, імпрэсіўна набліжаючы яе да ўспрымальніка. Азначальнае пытанне «Што гэта такое?» не рэлевантнае для пазнання цэласнасці. Частка цэлага не паўтараецца ў многім, г.зн. пазбаўлена магчымасці да абагульнення. «У мастацтве любое паўтарэнне не мае сэнсу» (Ортега-иГассет 227).

Дыскурсіўнай з'яўляецца, напрыклад, серыя раённых кніг «Памяць» (117 кніг), створаная па рашэнні кіраўніцтва Рэспублікі Беларусь у 2002 г. У ёй прадстаўлены гістарычныя факты, змешчаны біяграфіі вядомых асоб, 
якія адыгралі пэўную ролю ў развіцці таго ці іншага краю, здзейснілі ваенныя подзвігі або дасягнулі значных асабістых вынікаў і тым самым увайшлі ў гісторыю. Усе кнігі змяшчаюць багаты ілюстрацыйны матэрыял: здымкі дакументаў, краявідаў, асоб і да т.п. Як сам дыскурс, так i ілюстрацы да яго паведамляюць чытачу пра гістарычныя падзеі. Імі сведчацца асобныя факты. Чытач даведваецца пра лёсы людзей, здабывае цікавую культурную інфармацыю, г.зн. набывае веды. Дыскурс серы кніг адлюстроўвае гістарычны ўніверсум асобных раёнаў, якія аб'яднаныя ў адзіную сістэму.

Зусім з другой рэальнасцю сустракаецца чытач у кнізе У. Калесніка і Я. Брыля «Ніколі не забудзем». У ёй вайна паўстае вачыма дзяцей. Нічога не змяняючы і не дабаўляючы ад сябе, аўтары запісалі жывое слова тых, хто перажыў ваеннае ліхалецце. Рэспандэнты не былі проста сведкамі. Яны відавочцы ўсіх жахаў, якія іх не абмінулі. У кнізе не змешчана ніводнага здымку, адсутнічаюць дакументы. Чытач знаёміцца 3 фармальна незадакументаванай рэальнасцю - з жывым увасабленем у слове непасрэдна перажытага фенаменальнага вопыту.

Памяць мае прамы выхад у семіятычную сістэму мовы. Усё, што трэба запомніць, пэўным чынам пазначаецца (завязваецца свайго роду «вузельчык на памяць»). Знак - той жа напамінальны «вузельчык». Напрыклад, дарожныя знакі напамінаюць удзельнікам дарожнага руху аб неабходнасці знізіць скорасць, сігналізуюць аб магчымасці паяўлення на дарозе дзяцей, жывёл і г. д. Аб'яднаныя ў сістэму дарожныя знакі маюць на мэце дбаць пра бяспеку ўдзельнікаў дарожнага руху. Рознага роду памяткамі карыстаюцца існуючыя ў грамадстве інстытуцыі. Напрыклад, страхавая кампанія можа напомніць кліентам аб заканчэнні тэрміну страхоўкі машыны. Ветэранскія арганізацыі сведчаць памяць аб пенсіянерах віншавальнымі паштоўкамі з нагоды дзяржаўных свят. Не адна існуючая фірма з перакананнем сваёй значнасці дэкларуе: «Мы сваіх кліентаў помнім».

Пры ўсёй павазе да названых акцый, нельга, аднак, не прызнаць памяць адназначна асацыіруецца са смерцю, напр.: помнік ахвярам фашызму, захоўваць памящь аб загінуўшых героях, памінкі, успомніць усіх naiмeнна і г. д.; Momento mori (з лац. - «памятай пра смерць», «памятай, што смяротны»). Памінанне продкаў - рытуал, які, існуе і ў розных формах праяўляецца ў культурах свету. Помнікі і крыжы ставяць на магіле памерлых. Трагічны пафас гучыць, напрыклад, у творы А. Вярцінскага «Рэквіем па кожным чацвёртым». Памяць - доўг: аддаць доўг памяці.

Памяць належыць да анталогіі - ноўменальнага («у сабе») свету: быць у сабе, выйсці з сябе. Фразема помніць сябе азначае момант наяўнасці свядомасці (параўн. рус. вменяемость), неабходнасць валявога самакантролю: - Здурнеў саўсім! Як разгарачыщца, сам не помніць, што кажа! Не глядзіџь ні свайго, ні чужога, бацьку, матку не глядзіць! На мяне 
дак колькі разой сляпіщаю лез! Заслепіщь вочы - і лез! Не кажы проціў яго нічога! (І. Мележ).

У чалавечай ментальнасці прысутнічае супярэчлівая інтэнцыя: «помніць - гэта яшчэ не ўсё». Ёсць тое, што апрача памяці - супярэчыць ёй і стварае антыномію ўсім гістарычным меморыям. У адрозненне ад памятнага, незабыўнаму не характэрны пафас. Яно непадуладна свядомай волі і выбару, асэнсоўваецца як тое, што выпала на долю чалавека: шчаслівая доля, жаночая доля, прымацкая доля і др.; проціл. нядоля; Хацеў бы, каб доля У хатщы жыла, Каб з бурлівай рэчкай Нядоля сплыла (Купала). Феномен жыццёвага свету - доля - выступае антытэзай лёсу. Долю не выбіраюць; яна для чалавека «мая», а лёс заўсёды свой: Укожнага свой лёс, але: Ой, доля мая, доля.... (3 нар.). Займеннік свой указвае на месца ў сістэме (напр., быць на сваім месцы). Той, хто гаворыць «маё» не выказвае прэтэнзію ўласнасці, а выступае «мерай усіх рэчаў» (паводле Пратагора).

Ключавое слова рэальнасці, у якой адсутнічае гістарычная памяць незалежнасць. Феномен незалежнасці - найвышэйшая вартасць і памкненне чалавецтва: незалежнасць характару, незалежнасць думак, незалежная газета, незалежнае слова, незалежная дзяржава і др. Незалежнасць разумеецца ў сэнсе супярэчнасці: незалежна - у знач. прыназ. (у спалучэнні «ад») 'насуперак чаму-н.' (Тлумачальны 3: 367). Незалежнае стварае антыномію функцыянальнаму. Сістэмныя адносіны «функцыя» i «аргумент» не ўласцівыя таму, што не існуе, але парадаксальна ёсць. Не будучы ўцягнутым ў адносіны функцыянальнай залежнасці, логас (слова), аказваецца па-за схемай «дзейнік - выказнік». Ім гаворыць невыказнае.

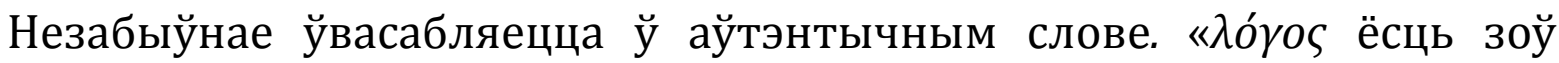
вярнуцца ад схаластыкі і адцягненнасці да жыцця» (Эрн 3). Феномен аўтэнтычнасці (сапраўднасці) сустракаецца толькі ў творчасці і жыцці. Апошняе, па сутнасці, і ёсць творчасць: сапраўдная паэзія, сапраўдны чалавек, сапраўднае жыццё і г. д. Аўтэнтычнасць словатворчасці выступае антыноміяй сістэмнай ідэнтычнасці. Дыскурсіўнае па прыродзе імя разлічана на памяць (напр.: успомніць усіх паіменна).

у аўтэнтычным слове ўвасоблена вітальнасць (ад лац. vitalis жыццёвы, жывы; vita - жыццё). Яго сутнасць увасоблена у метаназве жывое слова. 3 гісторыі вядома спроба інстытуцыяналізацыі згаданага феномена. Так, у 1918 г. ў Санкт-Пецярбургу быў створаны Інстытут жывога слова. Вучоныя інстытута прапанавалі мноства праектаў і праграм развіцця аратарскага мастацтва. Так, Г. Вінаградаў пісаў пра «народнае аратарскае майстэрства», маючы на ўвазе жывое вуснае слова.

Прыметнік жывое ў назве жывое слова мае сэнс, аналагічны як у назве жывы гук; параўн.: жыва 'наглядна, маляўніча': anicaць вельмі жыва і натуральна; жыва адгукнуцца (Тлумачальны 2: 261). Справа можа выклікаць інтарэс, а слова - ажыўленне. Жывасць і жвавасць - эталагічныя характарыстыкі рэчы, а не аб’ектыўныя ўласцівасці з'явы; параўн.: жвавы і 
рухавы. Жывая гаворка не адбываецца як праяўленая актыўнасць дзейнасць, а сама сабой праходзіць - ажыццяўляецца; параўн. пол. postępowanie; cp.: postępować "zbliżać się do kogoś, czegoś”, "zachowywać się, obchodzić się z kimś, czymś w pewien sposób"; postępowanie "sposób czyjegoś zachowania się" (Popularny 731-732). Гаворка - вербальныя паводзіны чалавека. У ёй адсутнічае валявое адценне і ўласцівасці дзейнасці; важным аказваецца ход яе ажыццяўлення (- Як усё прайшло? - Як пагаварылі?).

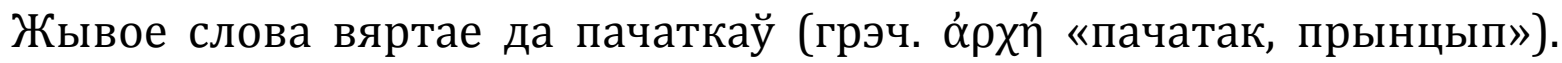
Тэрмінам пачатак («архэ») у філасофіі называецца сутнасць - нязменнае і вечнае ў шэрагу існуючых з'яў; «пачатак - аснова, крыніца, сутнасць чаго-н.» (Тлумачальны 4: 140). Слова пачатак валодае сэнсавай шматвектарнасцю. Ёсць некаторае «царства першапачатковасці»: жыццёвы пачатак, гуманны пачатак, творчы пачатак, паэтычны пачатак, крытычны пачатак і да т.п. Розныя сэнсавыя вектары слова пачатак катэгарызуюцца паняццем «суб'ектыўны пачатак». Фенаменалогія - шлях да даследавання ў мове творчай суб'ектыўнасці.

Не будучы аб’ектыўным адлюстраваннем рэчаіснасці, жывое слова ўвасабляе безназоўнае. Любая назва з'яўляецца сведчаннем існавання аб'ектыўных (прыродных) фактаў: зямля, сонца, вада і г.д. Аднак аб'ектыўна не існуе такіх фактах, як зямелька, сонейка, вадзіцца: Зямелька матка наша: $і$ корміць, i поіць, $і$ адзявае нас (3 нар.). Мая зямля, зямелечка, зямліца. Стаміўся я, дазволь мне прытуліцца Да баравых тваіх зялёных скроняў... (Г. Далідовіч). Увасобленая ў слове суб’ектыўнасць не дае яму магчымасці быць аргументам у справе. Аднак такая «немачная неаргументатыўнасць» аказваецца нябачнай сілай, якая пануе і ўплывае на паводзіны ўсяго жывога. У літаральным сэнсе выраз сапраўднае слова асэнсоўваецца як «слова праўды» і супрацьпастаўляецца сістэмна звязанай адзінцы - лексеме. Праўда не адкрываецца, але творыцца чалавекам. Няма іншай праўды, акрамя праўды жыция.

Слова не толькі само прыгадваецца, але і гаворыцца само: Гаварылася, жартавалася (Ф.Янкоўскі). У жывой гаворцы не праяўляе сябе дзеючая асоба «Я». Слова - не «дзела». Безасабовае ўжыванне дзеяслова гаварыць сведчыць аб нязмушанай натуральнасці аўтэнтычнага слова: ласкавае слова, жывое слова, салодкае слова і г. д. Яно як бы само сябе без удзелу таго, хто гаворыць, імперсанальна выяўляе: Не я гавару слова гаворыць; Гэта не я гавару - гора маё гаворыщь (3 гаворкі). Слова не адбываецца як падзея, а само знаходзіцца. Аднак яго выяўленчае «само» не азначае самадзельнае «само па сабе». Слова не актуальна самаснае, а патэнцыяльна самавітае.

Феномен творчасці ў тым, што паэт не сам піша вершы. Ён толькі запісвае падслуханае ў рэальнасці. Прыслухоўваючыся да мовы самой натуры - шуму ручая, шапацення лістоты і г.д., паэт імкнецца рэфлексіўна і непасрэдна ўхапіць сутнасць усяго і ўвасобіць у другой мове - метамове творчасці. Паводле Р. Барта, старажытныя грэкі «ўсхвалявана і нястомна 
ўслухоўваліся ў шэлест травы, у цурчэнне крыніц, у шум ветру, адным словам - у трапятанне прыроды, імкнучыся адрозніць разлітую ў ёй думку», то «так і я, услухоўваючыся ў гул слова, запытваю сэнс, які трапеча ў ім - бо для мяне, сучаснага чалавека, гэтае слова і складае прыроду» (Новейший 298). Аўтэнтычнасць выяўляецца ў слове паэтычным. Сапраўдная паэзія заўсёды «мета» - апрача ўсяго, што існуе як наяўнае і завершанае.

Сутнасць аўтэнтычнага слова інструментальна-пазнавальная. Слова творыць угледжаны вачыма мастака віртуальны свет сутнасцей. На самой справе (аб'ектыўна) ён не існуе, але сапраўды і з пэўнасцю для чалавека ёсць. Нельга не прызнаць таго, што ёсць увачавідкі. У сапраўдным слове ўвасоблены свет чалавечых упэўненасцей. Сэнс гаворкі ў тым, каб унікнуць у нешта, а не разабрацца з ім. Гавораць каб пазнаць рэчы - наблізіцца да іх сутнасці і «па ходзе» бліжэй пазнаць другога чалавекам. У адрозненне ад разумення, пазнанне аказваецца прынцыпова незавершаным.

У выдатнага беларускага лінгвіста і пісьменніка Ф. Янкоўскага не было сумневу ў тым, што «...само слова ёсць творчасць, а сама мова паэзія» (264). Што само слова ёсць творчасць, - падагульняе госць, асабліва чуещца, бачыцца адчуваецца, калі маеш справу з іншаю моваю, не сваёю роднаю, калі пазнаеш у ёй тое, што ні граматыка, ні лексікалагічныя даследаванні, ні слоўнікі не могуць, яшчэ не змаглі расказаць (Ф. Янкоўскі). Творчасць, як і жыццё, не прадпрыемства (справа), а стан выяўлення аўтэнтычнай суб'ектыўнасці чалавека. Словам творыцца жыццёвая рэальнасць - фенаменальны «для каго»-свет. Толькі ў творчасці чалавек суб'ектыўны.

Заключэнне i перспектывы даследавання. Фенаменалагічны падыход да мовы арыентуецца на пазнанне нязменнай сутнасці рэчаў таго супярэчлівага і парадаксальнага «ёсць», што ані было, ані будзе, ані можа быць, аднак увачавідкі ўвасоблена ў жывым слове, якое «само гаворыць» (паводле праф. Ф. М. Янкоўскага). Адзначаны падыход прадугледжвае, што мова з'яўляецца не толькі абстрактнай функцыянальна-знакавай сістэмай, але, што важна, ажыццяўляецца чалавекам, які гаворыць (Homo loquentes). Усе спробы выключыць чалавечую перспектыву з моўнай архітэктонікі свету немінуча вядуць да бяссэнсавасці і схематызму.

Істотнай прыметай мовы з'яўляецца яе антынамічнасць. Антыномія «памятнае - незабыўнае» ілюструе супрацьпастаўленне гістарычнага плану маўлення і археалагічнай рэальнасці, якая не звязана з часавымі каардынатамі, а асэнсоўваецца ў аспекце прасторавай аддаленасці - як далёкае мінулае, згаданае. Рэальнасць незабыўнага мае фенаменалагічны характар, належыць этасу жывога слова і паўстае ў вобразе незвычайнага. Памятнаму ўласціва аб'ектыўная фактаграфічнасць і іменная дыскурсія; яно асацыіруецца з ахвярнасцю і мае рытарычныя ўласцівасці. 


\section{Спіс выкарыстанай літаратуры}

Бахтин, Михаил. Эстетика словесного творчества. Москва: Искусство, 1989.

Брандист, Константин. «Исследование и преподавание живого слова и публичной речи в Петрограде-Ленинграде 1918-1932 гг.». Ежегодник Рукописного отдела Пушкинского дома. 2003 - 2004. - 2007, с. 58-82.

Лотман, Юрий. Избранные статьи: статьи по семиотике и типологии культуры. В 3 т. Т. 1. Таллин, 1992.

Новейший философский словарь. Минск: Современный литератор, 1999.

Павилёнис, Роландас. Проблемы смысла: современный логико-философский анализ языка. Москва: Мысль, 1983.

Тлумачальны слоўнік беларускай мовы. У 5 т. Мінск: “БелСЭ” імя П. Броўкі, 1977-1984. «Успомнім сваіх герояуџ». Раённыя будні, 4 Ліпень 2019.

Философский энциклопедический словарь. Москва: Советская энциклопедия, 1989.

Ортега-и-Гассет, Хосе. Эстетика. Философия культуры. Москва: Искусство, 1991.

Эрн, Владимир. Борьба за Логос. Минск: Харвест, 2000.

Янкоўскі, Фёдор. I за гарою пакланюся: апавяданні, абразкі, нарысы. Мінск: Мастацкая літаратура, 1982.

Янкоўскі, Фёдор. Само слова гаворыць: філалагічныя эцюды, абразкі, артыкулы. Мінск: Мастацкая літаратура, 1986.

Popularny słownik języka polskiego. Warszawa: PWN, 2002.

\section{References}

Bahtin, Mihail. Jestetika slovesnogo tvorchestva. Moskva: Iskusstvo, 1989.

Brandist, Konstantin. «Issledovanie i prepodavanie zhivogo slova i publichnoj rechi v Petrograde-Leningrade 1918-1932 gg.». Ezhegodnik Rukopisnogo otdela Pushkinskogo doma. 2003 - 2004. - 2007, pp. 58-82.

Lotman, Juri. Izbrannye stat'i: stat'i po semiotike i tipologii kul'tury. 3 vols. Vol. 1. Tallin, 1992. Novejshij filosofskij slovar'. Minsk: Sovremennyj literator, 1999.

Pavilionis, Rolandas. Problemy smysla: sovremennyj logiko-filosofskij analiz jazyka. Moskva: Mysl', 1983.

Tlumachal'ny sloŭnik bielaruskaj movy: 5 vol. Minsk: “BielSe” imia P. Broŭki, 1977-1984.

"Uspomnim svaih gerojau".Raennyya budni, 4 July 2019.

Filosofskij jenciklopedicheskij slovar'. Moskva: Sovetskaja jenciklopedija, 1989.

Ortega y Gasset, Jose. Jestetika. Filosofija kul'tury. Moskva: Iskusstvo, 1991.

Jern, Vladimir. Bor'ba za Logos.Minsk: Harvest, 2000.

Jankoŭski, Fjodor. I za garoju paklaniusia: apaviadanni, abrazki, narysy. Minsk: Mastackaja litaratura, 1982.

Jankoŭski, Fjodor. Samo slova gavoryć: filalagichnyja eciudy, abrazki, artykuly. Minsk: Mastackaja litaratura, 1986.

Popularny słownik języka polskiego. Warszawa: PWN, 2002. 